\title{
Tudományos szakmai szervezet, az akadémiai szektor és országos intézet összefogásának modellje a családorvos-szakképzés, az alapellátás kutatás-fejlesztési színterein
}

\author{
I. rész
}

\author{
Balogh Sándor dr. ${ }^{1}$ - Hajnal Ferenc dr. ${ }^{2}$
} ${ }^{1}$ Pécsi Tudományegyetem, Általános Orvostudományi Kar, Alapellátási Intézet, Családorvosi Tanszék, Pécs
${ }^{2}$ Szegedi Tudományegyetem, Általános Orvostudományi Kar, Családorvosi Intézet és Rendelő, Szeged

\author{
Mottó: \\ A múlt történései, eseményei és eredményei \\ mint használható iránymutatások \\ a jelenböl a jövőbe vezetólépések megtételéhez
}

\begin{abstract}
Az alapellátásban az általános orvosi gyakorlat optimális munkamódszere a családorvoslás, mely jól képzett szakembereket és az orvos és a család korrekt viszonyát feltételezi, illetve melyben érvényesülhet a betegségmegelőzés és a gondozás jó gyakorlata, a kedvezőbb forrásfelhasználás. A hazai egészségügyi reform része volt egy nemzetközi színvonalú családorvosi szisztéma kialakítása. Az 1967-ben alapított Magyar Általános Orvosok Tudományos Egyesületének szorgalmazására már 1974-től volt Magyarországon általános orvostani szakvizsga; a szakképzést a 6/1993. számú NM-rendelet indította el, mely a szolgálatban dolgozó orvosoknak felzárkóztató képzést és szakvizsgát írt elő. Segítette a hazai alapellátás fejlődését, hogy a szaktárca Európában egyedülállóan létrehozta 1998-ban az Országos Alapellátási Intézetet. Ezzel egy tudományos szervezet, az akadémiai szektor és országos intézet összefogása kezdődött a szakember-utánpótlásban, szakmapolitikai és népegészségügyi célok megvalósításában és a kutatás-fejlesztésben. A jelen munka visszatekint a kezdetekre, számot ad átfogó, lakossági szintű tudományos kutatások eredményeiről, bemutatja a családorvoslás munkájának eredményeit, alapot ad a jövőbeli fejlesztés irányaihoz, használható megállapításokat és a belőlük levonható következtetéseket mutat be.
\end{abstract}

Orv Hetil. 2018; 159(32): 1310-1316.

Kulcsszavak: általános orvostan, családorvoslás, országos intézet, egyetemi oktatás, szakorvosképzés, alapellátás, kutatás-fejlesztés

A model, by making common task force out of scientific organisation, the academic sector and governmental institute, was realised in Hungary to support the specific family physician training and to implement research and development projects in the primary healthcare

\section{Part I}

It is internationally recognized that the best method for practicing general medical care is family medicine, based on the correct relationship between the physician and the patients/families, where the principles of disease prevention and patient care meet, and the cost-benefit rates are better. In Hungary, a major part of the health reform had been the advancement of a primary care system by the international standards of modern family medicine. The Scientific 
Association of the Hungarian General Practitioners (SAHGP), founded in 1967, has adviced - from its onset - to introduce a new, independent medical specialty named 'general practice' which was finally realised in 1974 . That was followed, according to the Welfare Ministry Order No. 6/1993, by the specific training program for general practice which prescribed, also for the in-service GP-s, to complete an individual postgraduate training, to be ended by a state specialty exam in family practice, under conduction of the regional medical schools. Furthermore, for strengthening the primary healthcare, in 1998 the government established - uniquely in Europe - the National Institute of Primary Healthcare (NIPHC). So a unique task force has gained shape which included the academic sector, the professional NGO and the governmental background institution in order to manage: 1) human resource supply in PHC, 2 ) to implement statewide professional and public health goals as well as 3) to manage research and development projects. This paper takes a look back at the early events of this process as well as tries to offer an insight into the results and conclusions of the performed research projects, highlighting those which can be potentially usable in further professional development of the Hungarian PHC.

Keywords: general practice, family medicine, national institute, specific training, primary health care (PHC), research and development in PHC

Balogh S, Hajnal F. [A model, by making common task force out of scientific organisation, the academic sector and governmental institute, was realised in Hungary to support the specific family physician training and to implement research and development projects in the primary healthcare. Part I]. Orv Hetil. 2018; 159(32): 1310-1316.

(Beérkezett: 2018. január 31.; elfogadva: 2018. április 5.)

\begin{abstract}
Rövidítések
$\mathrm{BMI}=($ body mass index $)$ testtömegindex; Köjál = Közegészségügyi és Járványügyi Állomás; MÁOTE = Magyar Általános Orvosok Tudományos Egyesülete; MOTESZ = Magyar Orvos Társaságok és Egyesületek Szövetsége; OALI = Országos Alapellátási Intézet; OHI = Országos Háziorvosi Intézet; OKOI = Országos Körzeti Orvosi Intézet; OTKI = Orvostovábbképzó Intézet; POTE = Pécsi Orvostudományi Egyetem; SOTE = Semmelweis Orvostudományi Egyetem; UEMO = (Union Européenne des Medecins Omnipracticiens) Európai Családorvos Unió
\end{abstract}

A huszadik század hatvanas éveitól napjainkig hangoztatják az egészségpolitika és az orvosszakma nemzetközi véleményformálói, hogy az első vonalban, az alapellátásban az általános orvosi gyakorlat optimális munkamódszere a családorvoslás [1]. Ez egyrészt jelenti az általános orvosi szinten egységes rendszerben képzett, a szakma specifikumait is jól ismerő és alkalmazó szakemberek foglalkoztatását, másrészt az ellátó orvos és az ellátott család minden egyes tagjának egyedi, rendszeres, folyamatos és emiatt kölcsönös ismeretségen és tiszteleten alapuló viszonyát feltételezi. Általánosan elfogadott, hogy csak ebben a rendszerben képesek érvényesülni a megelőzés, a betegkövetés és a gondozás elvei, az ellátás költségei pedig jóval alacsonyabbak más modellekéinél.

A fejlett egészségügyi rendszerrel bíró országok az utóbbi öt évtized során egymás után tértek át a családorvosi modellre az elsődleges egészségügyi ellátás területén.

A hazánkban a rendszerváltáshoz kötődő egészségügyi átalakításnak (reform) is lényeges része volt az elsődleges ellátás régi rendszerének átalakítása a nemzetközi színvonalú családorvosi modell elveit és gyakorlatát követve. A reform előrehaladásának minden lépése ma- gával hozta az alapellátásban dolgozó orvosok szakmai hatáskörének bővülését; az 1992-ben elindított, majd napjainkig tökéletesített, illetve jogi, kormányzati változtatásokhoz igazított hatásköri (kompetencia-) lista ennek szellemében az előzőknél nagyobb szakmai mozgásteret - a vele járó szakmai felelősséggel és elvárásokkal karöltve - biztosít(ott) számukra [2]. A háziorvosi rendszer megvalósításának során figyelembe kellett venni azt a tényt, hogy a körzeti orvosi rendszerben nem biztosították és kontrollálták a szakmai színvonalat. Az ott dolgozó orvosok jelentékeny része szakképzettség, sőt előképzettség nélkül dolgozott. Az 1993-as felsőoktatási törvény a graduális képzés mellett a posztgraduális képzést is az egyetemek feladatává és kötelességévé tette, amely tény az orvosképzés területén a jelöltek elméleti és gyakorlati posztgraduális oktatását egyaránt akadémiai hatáskörbe helyezte [3]. A 6/1993. számú népjóléti miniszteri rendelet rendelkezett először a - gyermekkörzetekben dolgozó szakemberi közösség nevezéktani egyetértésével [4] - háziorvostaniként megnevezett szakképzésről: „... frissen végzett orvosok számára kötelező gyakorlati periódus diplomától számított 5 év, melynek 1-2. évét, mint rezidens kórházban, vagy egyetemi klinikán kell letölteni.” Előírta továbbá, hogy „az 1993. március 1-én a háziorvosi szolgálatban dolgozó orvosoknak 1998. december 31-ig a korábbi gyakorlattól függő egyéni képzési program teljesítése után szakvizsgát kell tenniük".

\section{A családorvoslás mint önálló tantárgy megjelenése az egyetemi oktatásban}

A magyarországi orvosképző helyek (akkor egyetemek, ma karok) gyakorlata a program kezdetekor igen eltérő volt. Az akkor még létező, posztgraduális képzésekre lét- 
rehozott és múködtetett Orvostovábbképző Egyetem lényegében teljes személyzetével és e célra allokált költségvetésével tudta felvállalni a többiek mellett a háziorvosi továbbképző programot, a Semmelweis Egyetem pedig kiemelt minisztériumi támogatással már 1992-ben profiltanszékkel rendelkezett, amely graduális oktatási feladata mellé nehézség nélkül tudta vállalni a diploma utáni képzést. Mindkettőjük munkáját segíteni tudta a helyben lévő Országos Háziorvosi Intézet. 1992-ben például a SOTE-n a Családorvosi Tanszék 15 millió forintos minisztériumi támogatással jött létre, a vidéki három orvosegyetem pedig 3-3 millió forintos pénzügyi támogatásban részesült 1993-ban a családorvoslás oktatásának megindítására. A vidéki egyetemeknek tehát lényeges központi támogatás nélkül, így Pécsett és Szegeden is nagyon hasonló módon, az egyetemek áldozatvállalása és a szakma iránt elkötelezett belső oktatók, valamint a régió lelkes, oktatást is vállaló szakembereinek az összefogása kellett az induláshoz. Mindkét városban 1992-ben alakultak meg a családorvostani oktatócsoportok, melyek feladata lett az orvostanhallgatók számára kötelezővé tett családorvostani graduális képzés, a felzárkóztató posztgraduális továbbképzés (1. fentebb!), valamint az 1992 decemberében elindult rezidensi rendszerü háziorvos-szakképzés.

\section{A tudományos szervezet tevékenysége a szakma fejlődésében, szerepe az egyetemi oktatás indításában}

A már említett, viszonylag későiként értékelhető akadémiai feladatkijelölés időpontját szerencsére messze megelőzte a szóban forgó - általános orvosi - szakmai közösség törekvése itthon arra, hogy szakmájukat mind más klinikus szakmákkal összevetve, mind a nemzetközi fejlődéshez csatlakozva, önálló szervezeti keretet kialakítva végezzenek tudományos tevékenységet, ezen belül kollegáikat segítsék az igényes, magas színvonalú ismeretszerzésben. Az ezzel a hitvallással testet öltött Magyar Általános Orvosok Tudományos Egyesülete (MÁOTE) 1967-es megalakulása óta az egyesület kitűzött céljaiért dolgozik. Kiemelten fontosnak tartotta és tartja ma is, hogy a körzeti/házi/családorvosok szakmai ismeretei minél eredményesebben legyenek megszerezhetők és bővíthetők mind az egyetemi, graduális oktatás és hallgatói orientáció/motiváció terén, mind az ennek folytatását képező szakorvosképzésben és a folyamatos továbbképzésben.

\section{Általános orvostani szakorvosi képesítés körzeti orvosok számára}

A szakember-utánpótlásképzés területén könnyebben tudott nemzetközi példákra hivatkozni az egyesület a diploma utáni képzést illetően [5], sőt ezen túllépve már 1972-ben szorgalmazta [6] az általános orvostani szakvizsga lehetőségének megteremtését és bevezetését. Az utóbbi végezetül 1974-ben vált lehetővé, és a szakmai érdekérvényesítés szép példája, hogy az alapot képező rendelet 5 éves képzési időszakot írt elő, benne 6 hetes Köjál-, 4 hetes sebészeti, 4 hónapos belgyógyászati és 2 hónapos gyermekgyógyászati gyakorlati elemeket munka mellett teljesíthető formában. Más kérdés, hogy a nemzetközi standardokhoz nem igazított, nem kellően támogatott és összehangolt (a gyakorlóhelyek szemszögéből inkább megtûrt), önként vállalható, tehát kizárólag teljes rendelői munkaidő mellett végezhető (kvázi) szakorvosképzés főként az OTKI-ra szorítkozott, nem véletlen tehát, hogy az általános orvostani szakvizsga megszerzése az első két évtizedben a körzeti orvosok motiváltságán, munkahelyük fơvárostól való távolságán, illetve munkáltatójuk támogatásán múlott.

\section{A graduális képzés kezdetei}

Graduális szinten a „körzeti orvoslás” sajátosként kiemelt témáinak szemelvényes, orientáció, szemléletformálás célzatú oktatása egy-egy klinikai tantárgy keretében, rendszerint társelőadói meghívás alapján kezdődött [7]. A nemzetközi haladó tendenciák ismeretében és a vázolt inkoherens helyzet miatt szorgalmazta a MÁOTE a megalakulása óta az akkor általános orvoslásnak nevezett, egyébként elvileg az akkori körzeti orvosi munka kívánatos szakmai tartalmát szisztematikusan összefoglaló tudományág önálló akadémiai diszciplínaként történő elismerését. A hivatalosan meghirdetett egyetemi tantárgyi oktatás hosszasabb küzdelem után az 1984/85-ös tanévben már megindult érdeklődő hallgatók számára a SOTE-n. Az Orvostörténeti és Szervezéstani Intézetben megalakult Körzeti Orvostani Oktatási Csoportból Andor Miklós és Arnold Csaba dolgozta ki a tantervet és teljesítette az oktatói feladatokat. A csoport 20 órában hirdethetett meg speciálkollégiumot, majd az évek során sikerült 10 órás kötelező, tantermi előadás formátumú oktatást megtartani negyed- és ötödévesek számára, illetve a belgyógyászaton belül a VI. évben a kéthetes körzeti orvosi gyakorlatot beiktatni. Ehhez szükségessé vált az oktatói kör kiszélesítése, a jelentkező orvosok kiválasztása, felkészítése és munkájuk szervezett irányítása, azaz a MÁOTE közelebb került vállalt küldetési céljainak eléréséhez, bizonyította, hogy szellemi és humán potenciálja, elkötelezettsége és szakértelme alapul szolgálhat(ott) az egyetemi szintű oktatás megindulásához és megvalósításához. A szervezet emblematikus tagjai közül Budapesten a már említett Andor-Arnold páros, Debrecenben Várallyay Gyula, Szegeden Morva László, Pécsen pedig Pataki László évek óta végzett és a helyi egyetemi vezetők által is ismert és elismert tudományos, szervező és szakértői munkájukkal igyekeztek a hallgatói oktatás létjogosultságát minél inkább elfogadtatni az érintettekkel, hálózatát pedig országosan egyöntetúvé tenni [7]. 


\section{A tudományos szervezet húszéves tevékenységének eredményessége}

A nemzetközi kapcsolatkeresésben és -kiépítésben, a kor színvonalának és a szakmai profilnak megfelelő tudományos tevékenység kezdeményezésében és támogatásában kezdettől védjegynek szánt nevéhez hüen mindent megtett ennek az alapvető céljának eléréséért. A teljesítés részeként „Medicus Universalis” címmel önálló szakfolyóiratot alapított a körzeti orvosok - elsôsorban szakmapolitikai - tájékoztatására, szakmai ismereteik bővítésére, nem kevésbé tudományos igényű munkáinak publikálására. Az akkor véleményvezér és/vagy „csak” ambiciózus, szakmai hitvallásuknak megfelelóen magas szinten munkálkodó körzetiorvos-kollégák által közölt cikkek mellett számos szakirányt képviselő orvosi tudományág szakemberei - sokak közülük olyanok, akik később elismert szaktekintéllyé váltak - publikáltak kezdetektől a lapban.

A MÁOTE történetének első másfél évtizede során további két fontos vívmány emelkedett ki a szervezeti múködés folyamából: 1) az „általános orvostani” szakvizsga elismertetése (1974) és az 2) Országos Körzeti Orvosi Intézet (OKOI) 1979. évi megalakítása a Pécsi Orvostudományi Egyetem (POTE) Egészségügyi Szervezéstani Intézetének bázisán (a kezdetekben állami támogatás nélkül). A folyamatosságot e téren a rendszerváltást követően az Országos Háziorvosi Intézet $(\mathrm{OHI})$ képviselte, mely ugyancsak nem önállóan, hanem a SOTE „köldökzsinórján” kezdte meg múködését, önálló országos intézménnyé pedig 1998-ban, Országos Alapellátási Intézet néven alakult át (l. lentebb).

A Surján László vezette Népjóléti Minisztériumban (1991-1994) eközben Jávor András irányításával azóta is példaértékűnek számító, az alapellátást átalakító munkálatsorozat kezdődött. 1992-ben a háziorvoslásról miniszteri rendelet jelent meg, mely taglalta a szakorvosképzés szabályozását, az állami rezidensi státuszok létrehozását, a felzárkóztató és szakorvosi átképzést, az önfoglalkoztató vállalkozási forma létrehozását, a háziorvosi teljesítményfinanszírozás bevezetését, a szabad orvosválasztást, a beutalási rend alapjait. Mindezek forradalmi újításoknak számítanak mind a mai napig, a kidolgozásukkal és bevezetésükkel együtt járó változások és egyéb következmények pedig döntően pozitív módon befolyásolják valamennyi, azóta zajlott/zajló egészségpolitikai változtatás és reformlépés irányultságát és jellegét egyaránt [8-12].

Kijelenthetô, hogy a MÁOTE a szellemisége és addigi folyamatos teljesítménye révén tudott kezdeményezője és meghatározó befolyásolója lenni az 1990-ben kezdődött egészségügyi „rendszerváltás”-nak, mindenekelőtt az alapellátás átalakításának.

\section{Országos intézet mint a családorvosi tudományág fejlesztésének és oktatásának támogatója, illetve az alapellátási kutatás-fejlesztésnek $(\mathrm{K}+\mathrm{F})$ a végzője, integrátora és koordinátora}

\section{A szakma országos intézetének szerepvállalásáról és tevékenységérōl dióhéjban}

1998-ban az OHI jogutódjaként, jelezve az alapellátás egységessé tételének szándékát, az akkori kormány a szaktárcához sorolt háttérintézményként létrehozta az Országos Alapellátási Intézetet (OALI), amelynek 1993ban, sok egyéb mellett, feladatává tette az éppen elindított (l. fentebb!), 60 státusszal és költségvetéssel létrehozott központosított háziorvos-szakorvosképzési - rezidens- - rendszer múköodtetését. A minisztériummal egyeztetve, az OALI nevében és Küldetés-nyilatkozatában, Alapító Okiratában is megfogalmazott országos hálózat kiépítése vált szükségessé az eredményes hatékony múködéshez. Az építkezést Szegeden, a szaktárca által 2000-ben koordináló tanszékké nyilvánított Családorvosi Intézettel kezdte meg az OALI, majd a további három orvosképző egyetem megfelelő tanszékeit is bevonta a folyamatosan erősített hálózati körbe. A három vidéki egyetem esetében az alakuló/megalakult tanszékek (1. fentebb is!) helyzetének erősítéséért az intézmények vezetésével megállapodva a tanszékek kubatúrájának kialakítására anyagi támogatást is nyújtott. Az OALI támogatása a kiemelt feladatot képezó háziorvos-utánpótlás, illetve az ellátásban részt vevő kollégák minőségi munkáját szolgáló regionális oktatótevékenység érdekében történt.

Az OALI az Országos Egészségpénztárnál, nem kevésbé a jogutód Nemzeti Egészségbiztosítási Alapkezelőnél e tekintetben az alapellátásra támaszkodó, ahhoz köthető kutatói irányvonalat nyitott meg. A közleményekben olvasható számok és magyarázatok pontosan az előbbiek miatt teszik jogossá meggyőződésünk szerint a forradalmi vívmány kitétel használatát [9-11].

Összességében: a leírtak és a jelen beszámoló kereteit tetemesen meghaladó „valódi” országos intézeti müködés néhány elemét felvillantva, utólag kijelenthető, hogy az 1992-ben 25 éves fennállását ünneplő MÁOTE a szellemiségének és szándékainak folytatását megvalósító alapellátói szakmák számára is létében mindvégig bázist, biztos múködési alapot képező, nemzetközileg is szinte egyedülálló országos háttérintézmény. 


\section{AZ OALI ÁLTAL VEZETETT/ VÉGZETT KIEMELKEDŐ VIZSGÁLATOK}

\section{Az Országos Alapellátási Intézet (OALI) 2002 és 2009 közötti vizsgálatainak összefoglaló eredményei}

9 vizsgálatban 184000 lakos adatai kerültek feldolgozásra.

Rizikó/lelet

Dohányzás:

A talált érték eltérése \%-ban

BMI $\left(25 \mathrm{~kg} / \mathrm{m}^{2}\right)$ :

Derékkörfogat (nő $80 \mathrm{~cm}$, ffi: $94 \mathrm{~cm}$ felett):

Magas vérnyomás gyakorisága

(140/90 Hgmm felett):

Emelkedett éhgyomri vércukor

(5,6 mmol/1; 6,1 mmol/1 felett):

Hypercholesterinaemia gyakorisága

(5,0 mmol/1 felett):

Hypertriglyceridaemia gyakorisága

(1,7 mmol/1 felett):

$17-43 \%$

$39-74 \%$

$37-54 \%$

$28-46 \%$

$13-35 \%$

$31-56 \%$

$28-47 \%$

A fenti összefoglaló adatok az Országos Alapellátási Intézet közel évtizedes kutató-elemző-összegző munkáját mutatják. A vizsgálati szám a levont következtetések alaposságát indokolhatja. Az eredményekben a látszólagos nagy szórást az eltérő célértékek, a vizsgált lakosság-, pácienscsoport eltérő köre magyarázza. A helyes következtetések levonását jelentő számszerüség mellett ez is felhívja a figyelmet, hogy mennyi és milyen széles merítésű okok és körülmények befolyásolják az egészségi állapotot, amit a mindennapi családorvosi ellátásban figyelembe kell venni. Az eltérő, az ellátást befolyásoló és meghatározó körülményeket különösen figyelembe kell venni, amikor az értékelésre, a „minőségi ítéletalkotásra” és az intervencióra kerül sor.

\section{Regionális egészségfelmérés}

1874 fös, Csongrád megyei reprezentatív minta az adott gyermek- és háziorvosi praxishoz tartozó egyének köréből random módon volt kiválasztva; retrospektív kérdőíves felmérés történt véletlenszerüen kiválasztott lakosok megkérdezésével, a háziorvosok asszisztenseinek közremúködésével. A kérdőív legfontosabb témakörei a szociodemográfiai, szociokulturális és szocioökonómiai körülmények voltak, így az egészségi állapotra vonatkozó kérdések, a megállapított és kezelt betegségek, az orvoshoz fordulás okai, feltételei és gyakorlata, az orvos utasításainak betartása, az öngyógyítás, a funkcionalitás csökkenése, a táppénzes betegnapok száma, a gyógyszerfogyasztási szokások, az életmód és az egészségmagatartás, a szüréseken való részvétel [13-16].

\section{„Gyorsfényképes” vizsgálat, 2002-2003}

A több mint nyolcvanezer lakoson történt felmérésben a cardiovascularis rizikó szintjének meghatározása történt. A napi betegellátás során a fokozott cardiovascularis rizikót vizsgáló kérdőíves felmérés, országos lefedettséggel, a családorvosi praxisok mintegy 10\%-ára kiterjedve, a 14 évesnél idősebb hazai lakosság körülbelül 1\%-ának bevonásával történt. A cardiovascularis rizikófaktorok listája és a rizikószintek a Magyar Hypertonia Társaság 2001. évi állásfoglalása és Greenland javaslata alapján kerültek összeállításra. Magas cardiovascularis rizikójú beteg volt, akinek diabetese, 180/110 Hgmm feletti vérnyomása, hypertoniás célszervkárosodása (szív, agy, vese, szemfenék) vagy manifeszt érbetegsége derült ki. Szintén magas rizikószintünek számított az a beteg, akinél a kérdőívet kitöltő orvos legalább 3 rizikófaktort tüntetett fel [17, $18]$.

\section{„CORPRAX” vizsgálat, 2003}

A cardiovascularis rizikószint meghatározása prospektív egyedi rizikófaktor-mérésen és Framingham-féle rizikóbesoroláson alapuló szû́rővizsgálat mintegy ötvenezer páciens bevonásával [19-22].

A vizsgálatokra a szív-ér rendszeri megbetegedések kialakulásában jelentős szerepet játszó rizikófaktorok gyakoriságának felmérése céljából került sor, az ország egész területét egyenletesen lefedve, 169 háziorvosi körzetben, a rendeléseken megjelentek közül a vizsgált páciensek véletlenszerü kiválasztásával, férfi-nő-férfi-nő sorrendet tartva. Felmérték a tápláltsági állapotot, a táplálkozási, ivási szokásokat, a stresszállapotokat, a vérnyomásértékeket, a vér totál- és HDL-koleszterin-, triglicerid- és cukorértékeit. A véletlenszerüen kiemelt páciensek esetében a napi betegellátási adatokat előre meghatározott protokoll alapján rögzítették. Bár a felmérésben 20 és 87 év közötti betegek vettek részt, döntő részben a 40-70 éves korú, vizsgálatra jelentkező egyéneket kérdezték ki. Nem volt ugyan elöírás arra, hogy egy-egy napon hány beteg kerüljön regisztrálásra, de a férfiak és a nők megközelítőleg egyenlő arányban szerepeltek.

\section{Kistérségi Egészség Napok, 2006}

A rendezvénysorozat keretében a 2006-os év folyamán 14 kistérségben egészségnapokat rendeztek, amelyeken a jelentkezők életkorát, nemét, dohányzási szokásait, fizikai aktivitását, tápláltságát, szisztolés és diasztolés vérnyomását, összkoleszterinszintjét, vércukoreredményeit rögzítették, és SCORE-pontérték-számításra is sor került. A vizsgálatra 7850 fó jelentkezett, $42 \%$ férfi és $5 \%$ nő, az átlagéletkor 48,7 év volt. Egészség Napok csak 10000 alatti lakosságszámú városban vagy faluban voltak $[23,24]$. 


\section{Az OALI-ban zajló vizsgálatok egy-egy szubspecifikus rizikóra}

Vizsgálódás történt, és megállapítások születtek a túlsúly, a testmozgás, a dohányzás és a kábítószer-használat témaköreiben [25-27]. Kitértek ezek az elemzések a területi eltéréseken túl a szociális rászorultság kérdéseire is [28].

A kétezres évek első évtizedének végén az OALI vizsgálatai már az eredményeket is kutatták, és igazolást találtak arra, hogy az elmúlt bő évtized háziorvosi és alapellátási intervenciói nem voltak eredménytelenek [29, 30].

Az Egészségpénztár 2000 és 2008 közötti gyógyszerfogyási adatai és a KSH mortalitási adatai összevetve retrospektív elemzésre kerültek a teljes 18 év feletti magyar populáció tekintetében. A KSH fogyasztási adatai közül a zsír-, az alkohol- és a dohányfogyás változásai, valamint az intervenciós kardiológiai eredmények is értékelésre kerültek ugyanezen időszak vonatkozásában. Az érdeklődés kiterjedt a stroke területére is [31].

\section{Következtetések}

2006-tól az OALI és az egyetemi oktatás számára az utánpótláshiány megoldása vált a legégetőbb problémává.

A jelenlegi körülmények között a családorvos-oktatás finanszírozási feltételei az egyetemek számára nincsenek biztosítva, így a már negyedszázados rendszer megújítása, múködtetése nagy gondokat okoz. Külön érdemes foglalkozni azzal, hogy milyen változások játszódtak, játszódnak le napjainkban. A munkaerő szabad vándorlása, a minden országban jelentkező orvoshiány, a szürkeállomány elvándorlása szinte megakadályozhatatlan. A lakossági elvárások, a laikus média hírei és a lokális érdekek együttes hatása célponttá tette az egészségügyet és fóleg a benne dolgozókat. Egy-egy hír, egy-egy vita mérhetetlen károkat okozott elsősorban a betegeknek, másodsorban az orvosoknak, nővéreknek. Az orvos-beteg, a beteg-egészségügy kapcsolat megváltozott, amihez hozzájárultak az elektromos média nemritkán ellenórizetlen információi, nem mindig segítve az egészségtudatosságot, fokozva a kételyeket. Pedig a gyógyításhoz bizalom kell, és korrekt viszonyok. Félve, de kimondható a morális deficit soha nem látott nagysága.

Amikor arról teszünk említést, hogy az elöregedő orvosgárda pótlását jelentő fiatalok egészségügybe jövetelét forszírozni kell, nem tudunk megbirkózni a fiatal korosztályok világának attitűdrendszerével sem. Sokat beszélünk a szakdolgozók és más egészségügyi szakmák szerepvállalásáról, és nem tudjuk, hogy ha orvosnak nincs elég jelentkező, akkor erre a területre van-e elegendő jelölt. Egyszerre van hiány és túlkínálat. Nincs középszintû́ szakdolgozóképzés. Amikor egy praxisban megürül egy ápolói állás, hónapokba telik a pótlás még a nagyvárosokban is. Van-e elég dietetikus, gyógytornász, otthon ápoló, fóleg a távoli vidékeken? Egyáltalán lehetséges-e és mikor, hogy az egészségügyben dolgozó ember egy munkahelye jövedelméből éljen meg biztonságban és megelégedettséggel?

Az általános orvoslás, a körzeti/család háziorvoslás elmúlt több mint fél évszázada, a kezdetektől napjainkig terjedő időszak történései, a múlt emblematikus alakjai, a közelmúlt reprezentánsai már csak kevesek emlékeiben élnek. Az emlékezés kötelez, a jövő kérdéseinek megoldásában pedig segít. Az adatok, elemzések, tudományos igényű dolgozatok összegyújtése, a mai korhoz igazítása a visszaemlékezésen túl a ma útkeresésében - mai szóhasználattal - „hozhat a konyhára” valamit. Legalábbis a korábbi évek munkái és a mostani múltba tekintésünk alkalmával megerősödött bennünk, hogy a témák további összefoglaló jellegû megírása érdemesnek látszik. Ezt mindezeken túl az egy-egy dolgozat terjedelme miatti korlátok is szükségessé teszik. Ami fontos, a most csak röviden említett, de jelentőségében kiemelt MOTESZ és MÁOTE égisze alatt megtörtént nemzetközi reprezentációja a magyar családorvoslásnak, kezdve az ötven év előtti időktől a közelmúlt négyéves Európai Családorvos Unió (UEMO) magyar elnökségi éveiig. Fontos téma, a jövő megoldásának lehetőségét megteremtő utánpótlás biztosítása, a képzés és szakorvosképzés kérdésének megtárgyalása az oktatópraxisok létesítésétől a fiatal pályakezdők motiválásáig.

Véleményünk szerint kiemelt kérdésekről van szó, melyek hiányában alap nélkül marad a magyar egészségügy, s múködése még nehezebb helyzetbe kerül, mint jelenleg van.

Anyagi támogatás: A közlemény megírása anyagi támogatásban nem részesült.

Szerzôi munkamegosztás: A szerzők egyenlő mértékben járultak hozzá a kézirat elkészítéséhez. A cikk végleges változatát mindkét szerző elolvasta és jóváhagyta.

Érdekeltségek: A szerzőknek nincsenek érdekeltségeik.

\section{Irodalom}

[1] Why a renewal of primary health care (PHC), and why now, more than ever? (World Health Report) WHO, Genf, 2008.

[2] Ministry of National Resources Hungarian G.P's Core Competencies. [A Nemzeti Erőforrás Minisztérium szakmai protokollja a Háziorvosi Hatásköri Listáról.] Egészségügyi Közlöny 2011; 61(7): 1317-1378. [Hungarian]

[3] 1993. LXXVI. Act on Vocational Training. [1993. évi LXXVI. törvény a szakképzésrôl.] Opten Törvénytár, Opten Informatikai Kft., Budapest, 1993. [Hungarian]

[4] 6/1993. Ministerial Decree of the Ministry of Welfare on the amendment of specialist training. [6/1993. Népjóléti miniszteri rendelet a szakorvosi képzés módosításáról.] Magyar Közlöny 1993; 18: 1-18. [Hungarian]

[5] Royal College of General Practitioners. The implementation of Vocational Training. Reports from General Practice VI. RCGP, London, 1967. 
[6] Editorial Notice. [Szerkesztőségi közlemény.] Medicus Universalis 1972; 5: 165. [Hungarian]

[7] Work of the District Medical Education Group. [Körzeti Orvosi Oktatási Csoport munkája.] Medicus Universalis 1985; 17: 376. [Hungarian]

[8] Balogh S. Experiences of family doctor retraining. [A háziorvos átképzés tapasztalatai.] Medicus Universalis 1996; 29: 329-336. [Hungarian]

[9] Balogh S. Family medicine in the mirror of social security data I First months of departure. [A háziorvoslás a társadalombiztosítási adatok tükrében I. Az indulás első hónapjai.] Medicus Universalis 1995 ; 28: 195-200. [Hungarian]

[10] Balogh S. Family medicine in the mirror of social security data II. About businesses. [A háziorvoslás a társadalombiztosítási adatok tükrében II. A vállalkozásokról.] Medicus Universalis 1995; 28: 261-264. [Hungarian]

[11] Balogh S. Family medicine in the mirror of social security data III. The third year. [A háziorvoslás a társadalombiztosítási adatok tükrében III. A harmadik év.] Medicus Universalis 1995; 28 : 293-296. [Hungarian]

[12] Balogh S. The first decade of family medicine. [A háziorvoslás első évtizede.] Orvostovábbképző Szle. 2003; 10: 10-15. [Hungarian]

[13] Belec B, Paulik E, Balogh S, et al. The effect of schooling on health status in Csongrád County. [Az iskolázottság hatása az egészségi állapotra Csongrád megyében] Medicus Universalis 2004; 37: 11-16. [Hungarian]

[14] Belec B, Paulik E, Balogh S, et al. Women's health and health care in Southern Great Plain counties. [A nők egészségi állapota és egészségmegtartása dél-alföldi megyékben.] Medicus Universalis 2004; 37: 171-175. [Hungarian]

[15] Müller A, Balogh S, Nagymajtényi L, et al. Factors affecting the child's health in the South Great Plain region; health promotion. [A gyermekek egészségi állapota, a szociális helyzet és az életmód összefüggései a dél-alföldi régióban.] Egészségfejlesztés 2006; 47: 36-40. [Hungarian]

[16] Paulik E, Balogh S, Belec B, et al. Epidemiological characteristics of obesity in the Southern Great Plain. [Az elhízás epidemiológiai jellemzői a Dél-Alföldön.] Népegészségügy 2004; 83: 12 17. [Hungarian]

[17] Balogh S, Hajdú N, Jánosi I. Assessment of cardiovascular risk factors I. [Kardiovaszkuláris kockázati tényezők felmérése 1.] Medicus Universalis 2003; 36: 143-150. [Hungarian]

[18] Hajdú E, Balogh S, Jánosi I. Assessment of cardiovascular risk factors II. [Kardiovaszkuláris kockázati tényezők felmérése 2.] Medicus Universalis 2004; 37: 17-23. [Hungarian]

[19] Balogh S, Kékes E, Császár A. Evaluation of cardiovascular risk factors in family medicine practices: the CORPRAX study. [A cardiovascularis rizikófaktorok felmérése háziorvosi praxisokban: a CORPRAX tanulmány.] Medicus Universalis 2004; 37: 3-10. [Hungarian]

[20] Kékes E, Balogh S, Császár A. Evaluation of cardiovascular risk factors in general practice. [A kardiovaszkuláris rizikófaktorok felmérése háziorvosi gyakorlatban.] Medicus Anonymus 2004; 37: 24-26. [Hungarian]
[21] Kékes E, Balogh S, Császár A. "Cardiovascular risk examination as the first stage of prevention" program in general medicine practices. [„Kardiovaszkuláris rizikóbecslés, mint a prevenció első lépcsője” háziorvosi praxisokban indított program.] Háziorvos Továbbképző Szle. 2004; 9: 136-139. [Hungarian]

[22] Kékes E, Balogh S, Császár A. Shocking statistics - a description of the results of the large-scale cardiovascular risk assessment program in Hungary. [Megdöbbentő statisztika - a hazai nagyszabású cardiovascularis rizikófelmérő program eredményeinek ismertetése.] Granum 2004; 7: 5-9. [Hungarian]

[23] Balogh S. Micro-regional cooperation, such as the possibility of structural change and the identity of public health issues. [A kistérségi együttmúködés, mint a struktúraváltás lehetősége és a népegészségügyi kérdések azonossága.] Medicus Universalis 2007; 40: 99-101. [Hungarian]

[24] Hargitai R, Balogh S. Micro-regional cooperation, such as the possibility of structural change and the identity of public health issues. [Kistérségi Egészségközpont - Az alapellátási struktúraváltozás lehetséges modellje.] Medicus Universalis 2007; 40: 9-13. [Hungarian]

[25] Császár A, Kékes E, Abel T, et al. Prevalence of metabolic syndrome estimated by International Diabetes Federation criteria in a Hungarian population. Blood Pressure 2006; 15: 101-106.

[26] Balogh S, Hargitai R. The general practitioner's options for dropping and caring for drug users. [A háziorvos lehetôségei kábítószerhasználók leszoktatásában és gondozásában.] Medicus Universalis 2008; 41: 73-78. [Hungarian]

[27] Balogh S. Spreading the minimum intervention for smoking in primary care. [A dohányzásra vonatkozó minimális intervenció elterjesztése az alapellátásban.] Medicina Thoracalis 2007; 60: 60-68. [Hungarian]

[28] Ujváriné Siket A, Balogh S, Becka É, et al. The need for care and the social need based on health status. [A gondozási szükséglet, valamint az egészségi állapoton alapuló szociális rászorultság vizsgálata.] Medicus Universalis 2009; 42: 13-19. [Hungarian]

[29] Balogh S, Papp R, Józan P, et al. Continued improvement of cardiovascular mortality in Hungary - impact of increased cardio-metabolic prescriptions. BMC Public Health 2010; 10: 422.

[30] Hajnal F, Busa C, Papp R, et al. The role of primary care professionals in preventive activitites during epidemics. Focus group assessment of the management of flu pandemic in 2009/2010. [Az alapellátásban dolgozó orvosok és munkatársaik preventív szerepe járványok idején: Fókuszcsoportokra alapozott szakmapolitikai hatáselemzés a 2009/2010. évi HINl influenzavilágjárvány tapasztalatairól.] Orv Hetil. 2017; 158: 523-532. [Hungarian]

[31] Papp R, Csaszar A, Paulik E, et al. Correlation between prescription of anti-hypertensive medication and mortality due to stroke. BMC Cardiovasc Disord. 2012; 12: 15.

(Balogh Sándor dr., Pécs, Rákóczi út 2., 7623 e-mail: balogh.sandor@pte.hu) 